\title{
Local Wisdom in the Use of Greeting Word of Minangkabau Society
}

\author{
Reniwati $^{1}$, Noviatri ${ }^{2}$ \\ $\left\{{ }^{1}\right.$ reniwati@hum.unand.ac.id, ${ }^{2}$ noviatri@hum.unand.ac.id \} \\ ${ }^{1,2}$ Universitas Andalas, Padang, Indonesia
}

\begin{abstract}
Greeting word is one of the very important language units in greeting. The incorrect choice of greeting word can sprinkle conflicts between people involved in the speech event. Minangkabau language has a greeting word. The shape is varied. The purposes of this study are to describe the forms of greeting words and explain the use of these forms. The author applied interviewing and observational methods that are described in a set of techniques. In analyzing the data, a pragmatic identity method is used which also described in a set of techniques. Data are obtained from a broad family of Minangkabau people in Nagari Sunua, Nan Sabarih District, Padang Pariaman Regency. The finding shows that there are various forms of greeting words. The emergence of diversity is related to the differences in generation and differences in the sociocultural position between the greeter and the interlocutors.
\end{abstract}

Keywords: Greeting Word, Language, Minangkabau, Sociolinguistics

\section{INTRODUCTION}

In [1] greeting has two meanings. The first meaning is an invitation to speak; greet; and saying. The second meaning is linguistic meaning, namely words or phrases which refer to each other in conversation and which vary according to the nature of the relationship between the speakers. The formulation of [2] about greeting limit it directly to the notion of greeting words, namely words that are used to greet, or to call the second person or the person being spoken to. From the definition above it can be said that the greeting word serves as an opening for a speech event. The definition of greeting word, term of address, or address form shows that the definition of them are diverse and have social dimensions. The diversity is based on the social dimension contain in the relationship between the speakers. Different nature of the relationship between them causes different form of the greeting.

Minangkabau is the name of a community group that has its own socio-cultural system. The community has its own language called Minangkabau, which functions as a communication tool for its people. Speech events that occur between communicants are the form of communication events. The use of greeting word which has social dimension can be found in the speech event.

The study of greetings in several languages has been carried out. The use of names and other words in calls (addresses) and in references (references) among American and European students who speak English is done by [3]. Data is taken from two forms of interaction, namely interactions between family members and interactions between students in academic 
institutions. The context or situation factor in a communication event is important in choosing the form of a call. The choice of vocation forms in Persian is reviewed by [4]. From the study, it was found that the discrepancy between the choice of using call forms with social factors and the context of communication events.

Research on greetings in Indonesian has also been carried out. The reseacher, [5] examined the sampeyan and you greetings used by students in Pasuruan and Probolinggo, the study of pragmatics. From this research, it is stated that these greeting words can be understood and used in different ways by students. This finding contributes to the knowledge that the use of the word sampeyan and you in people with higher social status is no longer considered an impolite expression because its use is a social norm in the community.

Many studies of greeting word in Minangkabau language have been done before. The researcher [6] conducted a study about greeting word in Minangkabau particularly in Agam Regency. Based on the result of data analysis there are two types of greeting words, namely 1) greeting words of relatives and 2) non-relative greeting words. Relative greeting word is divided into kinship words based on direct ties and indirect ties. Non-relative greeting word is grouped according to three fields: 1) customs, 2) religion, and 3) general. The next researcher, [7] conducted a comparison of greeting words in the family in the Minangkabau language with Malay language. The result shows greeting words owned by these two languages related to the order of siblings. Moreover, Minangkabau greeting word is more practical than Malay language. Furthermore, [8] conducted a study of greeting word in Minangkabau in Kenagarian Tuik IV Koto Mudiak Batang Kapas, Pesisir Selatan Regency. The results of his research is two types of greeting words are found, namely the greeting word of matrilineal kinship and the word of kinship based on marriage. In addition to this type of greeting word also found the word for non-relatives greeting. This matrilineal kinship of greeting word has many similarities to greetings used in marriage-based relationships. This greeting word is also used to greet other people outside of relatives. The next researcher, [9] conducted a comparison of the use of semiformal Minangkabau language greetings in Nagari Batuhampar District Limapuluh Kota and Negeri Sembilan Rantau Rembau area. From this study, it is found that the form of greeting word in semi formal majlis consist of titles, kinship terms, and forms containing plural numbers or plural meaning. These forms illustrate the composition of the people who participated in the majlis. The form of greeting words in both regions show more similarities than differences. In other article, [10] carried out the same study, but the data are collected in official majlis. The form of greeting words used in the migration area is more varied than in the area of origin. This is related to the composition of the audience which is indeed more varied in the migration area compared to the area of origin. Another finding is the number of similarities in greeting words is less than the differences. Other authors, [11] examined the use of the greeting in Minangkabau language and its implications toward the politeness of the language of community in Kampung Baru Village, Central Pariaman District, Pariaman City. The results of his research showed that two forms of greeting words, namely the greeting words of kinship in the nuclear family and greetings of kinship based on the extended family. In addition to the greeting words of relatives, it was also found the nonrelatives greeting words. The politeness of language in this community reflects the intimacy and mutual respect among fellow citizens. The greeting word research that links it with gender among students, one of which is a study conducted by Marlyna Maros, Aslinda Jhon, Mohd Baharim Mydin. The results show that if the social distance of students is close, they tend to use rather crude greeting strategies. For students who have a rather close relationship, female students are more comfortable using the name to say hello when men are in their habit of 
merely nodding their heads or saying "hi". The discussion ended by giving implied implications and also reserve some context for further study in greetings.

The previous study of greeting word as described above shows that there has been no study of the greeting word used in the extended family of Minangkabau people in Nagari Sunua, Nan Sabarih District, Padang Pariaman Regency. ${ }^{1}$ This research is important to be done because the form of greeting words tends to differ in almost every nagari. The purpose of the study is to describe the form of greeting word and explain their use.

\section{RESEARCH METHOD}

The author used observational and interview methods with a set of basic and advanced techniques that are following the object of this study in collecting the data. Furthermore, in analyzing the data the author applied a pragmatic identity method with the dividing-keyfactors technique as basic technique and the equalizing appeal technique, the distinguishing relationship technique and the comparative relationship technique to equalize the main thing technique as an advanced technique.

\section{RESULT AND DISCUSSION}

In the rules of alternation of the American greeting system formulated by [12] there are previous selectors generation who refer to the ranking of generations. ${ }^{2}$ This rule implies that some generation ratings and this generation rankings influence the choice and the use of greeting words. The generation rating is divided into generations under the greeter, similar generation or one generation with the greeter, and generation above the greeter. The greeter becomes the starting point in determining the form of greeting words that will be used for interlocutor and in anthropology this is termed as ego (abbreviated as E). In [1], generation is defined as all people who are about the same life span. Based on this definition, the generation under the greeter is all whose life is below the greeter. The generations which are similar to the greeters are on the same line as greeters. Furthermore, the line of people including the generation above the greeter lies above the line of the generation.

Talking about the form of greeting words cannot be separated from the rank of generation. In this generation ranking is attached the type of kinship relationship between greeters and interlocutors in the extended family. This type of kinship relationship is also inseparable from socio-cultural status in the extended family. The discussion of the greeting word forms is divided into three levels above the greeter generation, namely the generation of greeters (E), one rank generation above the greeter, and the two-ranked generation above the greeter.

Relatives belonging to the rank of generation with greeters are siblings and cousins from the mother's part of the greeter. The relatives for one generation above the greeter are mother and father of the greeter and mother's brother. On the other hand, relatives who are included in the two generations above the greeter are grandmother and grandfather of the greeter and the mother's brother of grandmother. Brothers of the fathers and grandparents are not included to the relatives of mother or grandmother according to the sociocultural system of Minangkabau

\footnotetext{
${ }^{1}$ The extended family is a family consisting of similar mother'. Anthropology experts, [13] say that the extended family of Minangkabau consists of senior nuclear families with senior nuclear families of female siblings and nuclear families of all female children.

${ }^{2}$ [14] Generation is one of the 9 universal principles that distinguish one type or class of relatives from another type or class of relatives.
} 
community. The types of kinship relationships or socio-cultural status of interlocutors in the family are available in here.

In this generation's ranking, gender and age factors determine the choice of greeting words. These two factors are part of the American English greeting system formulated by [13]. Both are selectors in the process of selecting greetings. The interlocutors can be younger, similar age, or older than greeters.

\subsection{GREETING WORDS FOR GREETER'S GENERATION}

The people who are in the same generation with the greeters consist of siblings and cousins of the mother's half. The form of the greeting word varies and depends on the age of the interlocutor. If the interlocutor is younger than the greeter or the same age as the greeter, then the interlocutor is called by his own name ${ }^{3}$. In his article [15] states that name is one type of greeting word form. The name itself can be in the form of a short name ${ }^{4}$ and nickname. An example of a woman's name, Yat, is a short name taken from the third syllable of her long name, Noviatri. Example of a male name, Mas is a short name taken from the first term of a long name, Masdi.

Beside the name, according to [15] , the second person pronouns can also be a form of greeting. In the area of study is also found the use of this form as a greeting. The form is (wa) ang- (wa) ang ( $\mathrm{ka}$ ) sadoe is addressed to plural men and (wa) ang for single men and (a) kau(a) (kau) (ka) sadoe is addressed to plural women and (a) kau for single women and kaliankalian is (for men and women) plural. If the interlocutor is the same age as the greeter, then the greeting is awak-awak for male and female plural and awak for single men or women. Among people of the same age, greeting words are used in the form of phantom expressions, such as $a i, o i$, and $o i h$. These words are used for singular and plural.

There are some forms of greeting word used for a generation of siblings who are older than the greeter. The forms of the greeting word are uni (to the older sister) or ajo (to the older brother). Another variation of this form is $n i$ or jo followed by someone's name. The structure is $n i$ / jo + name (short name) / other form of greeting. If the interlocutor's status is a cousin who is older, same age, and younger than the greeter the rules for the greeting are similar to the rules for greeting the siblings. The form of greeting word above is addressed to one person (single). The form of greeting word addressed to many people (plural) is different from the form of greeting word addressed to a single man. The form of the greeting word also depends on the age. If the interlocutor is older than the greeter, the form of the greeting is similar to the form of single greeting word, but the repetition is used for that form or by adding of the word kasadoe or sadoe. The structure is ajo-ajo / uni-uni) + (ka) sadoe.

In addition to the form of the greeting above, there are other forms of greeting used in the area of study, namely teta, ayang, elok, uniang, taci, or one. The order of this greeting form is in accordance with the birth order. This greeting word appears when the number of siblings is more than one person. This greeting rule also applies to cousins.

\footnotetext{
${ }^{3}$ Regarding someone's name, [16] found a tendency for different rows of sounds in the names of men and women. Women's names tend to be patterned i-a, o-a, and a-a-a-a. While men's names tend to be patterned like u-a, a-i-o, and a-i-i.

${ }^{4}[16]$ classify the origins of short names over 4 groups, namely short names taken from (1) the beginning of a long name; (2) middle of a long name; (3) the end of a long name; and (4) completely different from long names.
} 


\subsection{GREETING WORD FOR ONE GENERATION ABOVE THE GREETER}

People who are one generation above the greeter consist of mother, mother's brother and father. The first form of greeting word would be discussed is the greeting word for mother. The greeting words used are varies, such as $i b u$, amak, one, cani. The greeting word used to greet mother's sister is the same as the greeting word used to greet mother. However, if the greeting word for $i b u$ is used as a reference, it is usually added with a name, such as $i b u$ Nurlis, amak suna, one suarni, or cani jani. The greeter considers the mother's sister like her own mother.

Father is not included in his wife's family because he lives in his wife's extended family. The form of greeting word for father is also discussed in this article. Ego (greeter) greets his/her father also in various forms. The greetings words are abak, ayah and papa. ${ }^{5}$ Each form has variations, that is, bak, yah, and $a p a$ or $p a$ which is a fragment of the previous complete form.

Now the discussion is about the greeting words for mother's brother. The status of a Minangkabau man is as 'mamak' or uncle for the children of his sister. While those children are the nephew for that mamak or uncle. The kinship between a man and a daughter of his sister is called the kinship of mamak kemenakan or uncle and nephew [17]. As a mamak, he has the duty as a mamak in Minangkabau. The form of greeting words to that mamak also depends on the order of the siblings. This form is a combination of mak with the name of the sequence of brother and sisters. The word mak is the result of decapitation of mamak. The full form is shown in the table below.

Table 1: Bother and Sister Greeting Words for Mother's Brother

\begin{tabular}{|l|l|}
\hline Order of Brothers & Greeting Words \\
\hline First & mak adang, mak dang \\
\hline Second & mak angah, mak ngah \\
\hline Third & mak etek, metek \\
\hline Last order & mak uncu, muncu \\
\hline
\end{tabular}

If a mother has more than three brothers such as four or five and so on, the form of greeting is mak + (his skin color). The tendency of skin color which also forms the greeting words is white, straight yellow, and black. Examples are mak utiah, mak uniang, and mak itam. The main element, uniang, utiah and itam are the taken form the part of Putiah, Kuning, and $(h)$ itam. From the table above we can see that the form of the greeting word for mamak has various forms. The form of mak dang comes from the long form of mak gadang which the shortening become mak adang. The form mak ngah or mak angah is a shortening of mak tangah. Similar to mak dang, and mak ngah, metek and muncu are also the shortening of a long form, namely mamak ketek and mamak bungsu. Uncu is the result of shortening and changing sound from the the form bungsu to bonsu or bunsu and finally become onsu.

\subsection{THE GREETING WORD FOR TWO GENERATION ABOVE THE GREETER}

Two generations above the greeter consists of grandmother, grandmother's brother, and grandfather. The form of the greeting word to grandmother is anduang. The variations of form

${ }^{5}$ Following the explanation of [19], other forms of greeting words, mama and papa appeared during the Dutch colonial period. 
are nduang and duang which is the shortening from the original form. This greeting rule also applies to grandmother's brother. However, the form of the greeting is slightly different from the form of greeting words to grandmother. The difference is the addition of someone's name. The structure is anduang/nduang / duang + name.

Next is a greeting words for grandfather. Grandfather lives in the house of his spouse's extended family, grandmother. Therefore, the greeting word for grandfather is also discussed. As with the son-in-law, the grandmother's husband also posed as a minantu (son-in-law) for his wife's parents or sumando (semenda) viewed from his wife's mother or grandmother's kinship group. Nevertheless, they are respected by other family members. The form of this grandfather's greeting is ungku. This form also has variations, i.e. or $n g k u$ or $k u$ as the shortening from the original form.

From the discussion above we can see the variation of greeting words form. That diversity has been formed by the generation of ranks in the extended family. This generation ranking also shows the sociocultural status of the interlocutor in the family or the type of kinship between the greeter and the interlocutor. The choice of the greeting word form to be used also depends on the sex and age of the interlocutor. These social categories form the system of addressing. Therefore, people must use the correct and appropriate form of greeting in accordance with the applicable greeting system. Minangkabau people have a kind of daily speaking manners each other, according to their social status [17]. It is called kato langgam. The greeting system is included in to langgam kato. The rules applied in the greeting system reflect the manners in communication. Minangkabau people must understand and carry out the manners in life. If this rule is violated, then the person who violates it is considered as someone who does not know the manners in communication. This may cause offense and then develops into a conflict. Those who practice manners mean they carry out politeness strategies in communication. According to [18] politeness is a strategy to avoid conflict, and maintain the respect. That person cares to someone's face, the speaker and the interlocutor's face [19].

\section{CONCLUSIONS}

The greeting word of Minangkabau language in Nagari Sunua, Central Pariaman City shows a variety in forms. This variation is formed because the choice of greeting word form must consider the generation rank which explains the type of kinship relations between the greeter and interlocutor and the greeter's socio cultural status. Social categories such as gender and age of the greeter also determine the selection of greeting words. Although the greeting words have many variations, the forms of those greeting words have rules and systems. Therefore, speakers of the Minangkabau language in the area must obey the system to avoid conflict. The people who avoid conflict mean that they have shown courtesy to the interlocutor.

\section{Acknowledgements}

The author expresses gratitude to Fakultas Ilmu Budaya Universitas Andalas and Program Studi Sastra Minangkabau Universitas Andalas.

\section{REFERENCES}

[1] Kamus Besar Bahasa Indonesia. 2019.

[2] Chaer, Tata Bahasa Praktis Bahasa Indonesia. : Bharata Karya Aksara, 2000. 
[3] Dickey, E. (1997). "Forms of Address and Terms of Reference". Journal of Linguistics. 33 (02). 255-274. Cambridge University Press.

[4] Kesahavarz, M. H. (2001). "The Role of Social Context, Intimacy, and Distance in the Choice of Forms of Address". International Journal of Sociology of Language University for Teacher Education Teheran. 148 (2001). 5-18.

[5] Susanto, Djoko. "The Pragmatic Meanings of Address Terms Sampeyan and Anda". Indonesian Journal of Applied Linguistics, Vol. 4 No. 1, July 2014, pp. 140-155.

[6] Syafyahya, Kata Sapaan Bahasa Minangkabau di Kabupaten Agam. Pusat Pembinaan dan Pengembangan Bahasa, 2000.

[7] Media Sandra Kasih, "Sistem Sapaan Keluarga Bahasa Minangkabau dan Melayu Suatu Perbandingan," in Menelusuri Jejak Melayu-Minangkabau, Yayasan Citra Budaya Indonesia, 2002.

[8] F. R. Utama, Emidar, and E. Arief, "Kata Sapaan dalam Bahasa Minangkabau di Kenagarian Tuik IV Koto Mudiak Batang Kapas Kabupaten Pesisir Selatan,” Markah, 2012.

[9] Reniwati and Ab. Karim Ab. Razak, "Kata Sapaan Separa Rasmi dalam Masyarakat Minangkabau di Kabupaten 50 Kota dan Daerah Rembau: Suatu Kajian Perbandingan," International Journal of the Malay World and Civilisation (Iman) 3(2), 2015.

[10] Reniwati and Ab. Karim Ab. Razak, "Perbandingan Kata Sapaan Rasmi Bahasa Minangkabau dan Dialek Negeri Sembilan," Dewan Bhs. dan Pustaka, 2015.

[11] Novendra, Ermanto, and Ngusman, "Penggunaan Kata Sapaan Bahasa Minangkabau dan Implikasinya terhadap Kesantunan Berbahasa Masyarakat Desa Kampung Baru Kecamatan Pariaman Tengah Kota Pariaman,” Bhs. dan Sastra, vol. 5, no. 1, 2017.

[12] Ervinn Tripp, "On Sociolinguistics Rules: Alternation and Co-occurrence," in Directions in Sociolinguistics, New York: Holt, Rinehart and Winston, Inc, 1986.

[13] Koentjaraningrat, Pengantar Antropologi II. Jakarta: Rineka Cipta, 1997.

[14] Koentjaraningrat, Beberapa Pokok Antropologi Sosial. Jakarta: Dian Rakyat, 1990.

[15] F. Ralph, The Sociolinguistics of Society. New York: Blackwell Publishing, 1984.

[16] Reniwati, "Struktur Fonologis Nama Orang Minangkabau," Wacana Etn., vol. 1, 2010 .

[17] A. . Navis, AlamTerkembangJadi Guru: Adat dan Kebudayaan Minangkabau. Jakarta: PT Grafittipres, 1984.

[18] L. Geoffrey, Principle of Pragmatics. London: Longman, 1991.

[19] P. Brown and S. C. Levinson, Politeness Some Universals in Language Usage. New York: Cambridge University Press, 1987. 